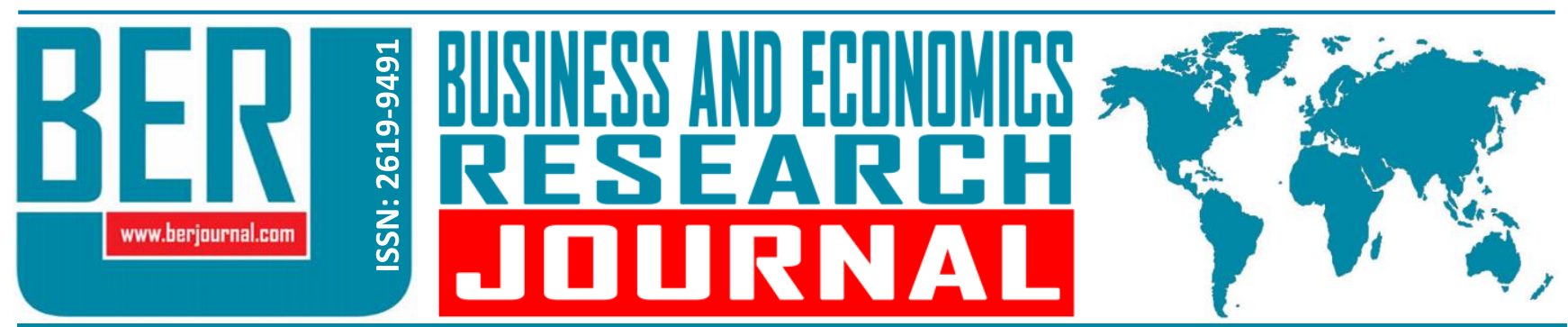

Business and Economics Research Journal Vol. 10, No. 4, 2019, pp. 945-958 doi: 10.20409/berj.2019.212

\section{Esnaf ve Sanatkârların Ahilik Değerlerine Sahip Olma Durumlarının Bazı Değişkenler Açısından Belirlenmesi: Kurşehir Örneği ${ }^{1}$}

\author{
Musa Ozata ${ }^{\mathrm{a}}$, Emine Sener ${ }^{\mathrm{b}}$
}

Öz: Bir çalışma ahlakı sistemi olarak Ahilik, yüzyıllar öncesinden günümüze kadar adından söz ettiren bir sistemdir. Bu çalışmanın amacı Kırşehir esnaf ve sanatkârlarının Ahilik değerlerine sahip olma durumlarının bazı değişkenler açısından belirlenmesidir. Araştırma evrenini Kırşehir'de yaşayan esnaf ve sanatkârlar ile bunların yanında çalışan kişiler oluşturmaktadır. Araştırma tanımlayıcı nitelikte olup, verilerin toplanmasında yüzyüze anket tekniğinden faydalanılmıştır. Verilerin toplanmasında Ahilik Değerler Ölçeği kullanılmıştır. Araştırmada toplanan veriler SPSS 20.0 programında analiz edilmiştir. Veriler üzerinde tanımlayıcı istatistikler, Mann Whitney U Testi ve Kruskal Wallis Varyans Analizi testleri yapılmıştır. Ayrıca ölçeğin geçerliliğini test etmek için Açımlayıcı Faktör Analizi uygulanmıştır. Ölçek puanlarının yaş, cinsiyet, görev ve öğrenim durumu açısından istatistiksel olarak anlamlı olduğu belirlenmiştir. Çalışma sonuçları incelendiğinde esnaf ve sanatkarların Ahilik değerlerini yeterince benimsemedikleri görülmüş̧ür. Bulunan bu sonuç diğer araştırmalarla da benzerlik göstermektedir.

\section{Determination of the Tradesman and Craftsmen's Levels of the Ownerships of Akhi-Order Values in terms of Some Variables: Sample of Kırşehir Province}

Abstract: As a work ethics system, Akhism is a system that is talked about from centuries ago to now. The aim of this research is evaluation of tradesman's and craftsmen's levels of the ownership of Akhi_Order Values in terms of some variables in Kırşehir. The research population consists of tradesman's and craftsmen's and the workers who work together with them, living in Kırşehir. The research was descriptive and the face-to-face survey technique was used to collect the data. The data collection was performed using the Akhi Order Values Scale. Descriptive statistics, Mann Whitney U test and Kruskal Wallis variance analysis were performed on the data. In addition, exploratory factor analysis was applied to test the validity of the scale. Scale scores were statistically significant in terms of age, gender, duty and educational status. Research findings show that Kırşehir tradesman and craftsmen have adopted Akhi values at an intermediate level. When the results of the study are examined, it was seen that tradesman and craftsmen's did not adopt the values of Akhi. This result is similar to other studies.
Anahtar Sözcükler: Ahilik, Ahilik Değerleri, Esnaf ve Sanatkârlar, Çalışma Ahlakı, Kırşehir

JEL: D23, M10, M12

$\begin{array}{ll}\text { Geliş } & : 26 \text { Mart } 2019 \\ \text { Düzeltme } & : 17 \text { Mayıs } 2019 \\ \text { Kabul } & : \text { 14 Haziran } 2019 \\ \text { Tür } & : \text { Araştırma }\end{array}$

Keywords: Akhism, Akhism Values, Tradesmen and Craftsmen, Work Ethics, Kırşehir

JEL: D23, M10, M12

$\begin{array}{ll}\text { Received } & : 26 \text { March } 2019 \\ \text { Revised } & : 17 \text { May } 2019 \\ \text { Accepted } & : \text { 14 June } 2019 \\ \text { Type } & : \text { Research }\end{array}$

a Prof., PhD., Kirsehir Ahi Evran University, Faculty of Economics and Administrative Sciences, Department of Business Administration, Kirsehir, Turkiye, musaozata@gmail.com (ORCID ID: 0000-0003-1742-0215)

b Asst. Prof., PhD., Kirsehir Ahi Evran University, Faculty of Economics and Administrative Sciences, Department of Business Administration, Kirsehir, Turkiye, eminesener@gmail.com (ORCID ID: 0000-0002-8903-1684) 


\section{Giriş}

Türk örf ve adetlerinin İslam inancı ile yoğurulması sonucu ortaya çıkan ve yaklaşık beş yüz yıl boyunca Anadolu'da esnaf ve sanatkârların teşkilatlanma birliği olan Ahilik Kurumu; tarihsel süreçte ekonomik, sosyal, askeri ve toplumsal konularda birçok büyük işlevi yerine getirmiştir. Bu özellikleri nedeniyle günümüzün sosyal güvenlik, meslek odası, sendika, belediye, kalite ve çalışma ahlakı kurumlarının temelini oluşturduğu söylenebilir.

Ahilik, fütüvvet ortamında doğan ve mutasavvıflarca tespit edilen fütüvvet ilkelerinden etkilenen, fakat fütüvvetin bir devamı olarak da görülmeyecek olan, Türk Milletine ait tarihi ve kültürel değerlerle, İslam dinine ait değerlerin bir sentezinden oluşan, Türk Milletine özgü bir kurumdur. Bu kurum Türk Milletinin yaklaşık bin yıllık Anadolu'daki varlığı esnasında onun dini, ahlaki, iktisadî, siyasî ve sosyal hayatına yön vermiştir (Akça, 2003: 217). Ahilik, tasavvufî bakış açısının meslek hayatında uygulanması üzerinde durmuş̧tur. Böylece Anadolu'daki Müslüman Türkler üzerinde asırlar boyunca etkisini sürdüren bir sosyal yardımlaşma ve dayanışma müessesesi haline dönüşmüştür. Aynı zamanda üyesi olan esnaf ve sanatkârların dini ve meslekî yönlerden yetiştirilmesini esas aldığından yaygın eğitim kurumu olma vasfını da kazanmıştır (Akgündüz, 2014: 17).

Literatürde genel olarak Ahi kelimesinin Arapça kökenli bir kavram olduğu ve "kardeşim" anlamına geldiği belirtilmekle birlikte, kelimenin Türkçe kökenli olduğunu iddia eden görüşler de yer almaktadır. Bu görüşe göre eski Türkçe eserlerde yer alan bu kelime "cömert, eli açık, yiğit" gibi anlamları ifade eden "Akı" kelimesinden gelmektedir. Çağatay'a göre ise Ahi kelimesi köken itibariyle Orta Asya'dan gelmiştir. Anadolu'da bütün Türk kurum ve terimlerinin Arapçaya çevrilmesine dair gayretlerin arttığı bir çağda Türkçe olarak ifade edilen akı kelimesi, Arapça Ahi kelimesine dönüştürülerek telaffuz edilmiştir (Çağatay, 1989: 44).

İslâm tarihinde ilk asırlardan itibaren görülen fütüvvet teşkilatının devamı sayılan ve esnaf ve sanatkârlar birliği olarak karşımıza çıkan Ahilik Teşkilatı, XIII. asırda kurulmuş olup (Akgündüz, 2014: 9), Anadolu'nun yurt edinilmesinde ve Osmanlı İmparatorluğu'nun inşa edilmesinde büyük bir rol oynamıştır (Ceylan, 2013: 12). Selçuklu devlet otoritesinin zayıfladığı bir dönemde kargaşanın önlenmesi ve düzenin sağlanması amacıyla şehirlerin yönetimini adeta Ahiler üstlenmiştir. Bu zamanda Ahilik, şehirlerin siyasi, idari, iktisadi, askeri yapısını koruyan ve emniyeti sağlayan yegâne kuruluşlar haline gelmiştir. Ahilik sayesinde devletin hiçbir tesiri olmadan şehir esnafı ve halkı kendi kendisini idare ederken en küçük bir mesleki suiistimal, yolsuzluk ve geleneğe aykırı bir harekete fırsat verilmemiştir (Turan 1993: 21; Akt: Akgündüz 2014: 10).

Anadolu'da Ahiliğin kurucusu ve halk arasında "Ahi Evran" olarak bilinen Şeyh Nasiruddin Mahmud (1172-1262), Azerbaycan'ın Hoy şehrinde doğmuştur (Malkoç, 2016: 10). Çok yönlü ilim ve fikir adamı olarak bilinen Ahi Evran, 1205'te kayınpederi ile Kayseri'ye yerleşerek deri işletmeciliği anlamına gelen bir debbağhane kurmuştur. Aynı zamanda şeyhi ile Anadolu'nun birçok kesimini dolaşarak halkın ekonomik sosyal yapısını incelemiştir. Halkın içinde bulunduğu sorunları yakından görerek oluşturduğu örgütün felsefesinde, yaşadığı olaylardan esinlenmiştir. Ahi Evran gezdiği yörelerdeki beyleri ve o kesimin ileri gelenleri ile görüşerek onları dergâh ve zaviyeler oluşturmalarına yönelik teşvik etmeye çalışmışır. Ahiliği esnaf ve sanatkârlar nizami halinde kurmaya çalışan Ahi Evran, Ahilik anlayışının örgütlenmesinde ve geniş bir çevreye yayılmasında öncülük etmiştir (Demir, 2004:6).

Tüm kurallarını dinin asıl kaynağından esinlenerek ortaya koyan Ahiliğin nizamnâmelerine Fütüvvetname denilmektedir (Sancaklı, 2010: 4). Kendini insanlara ve topluma adamak anlamlarına gelen Fütüvvet, "feta" kelimesinin türetilmiş halidir. Ahiliğin esasını meydana getiren "feta" kelimesi ise genç, delikanlı ve yiğit anlamlarını ifade etmektedir (Arslanoğlu, 2004: 101). Fütüvvet esas itibariyle tasavvufa dayanarak iktisadi teşekkülleri de bünyesinde barındıran örgütlenmeye verilen isimdir. Bu çerçevede fütüvvet mesleğine girenlerin şeyhlerine Ahi adı verilmektedir (Çakmak, 2014: 149). Bakır’a (2014: 407) göre Ahilik kurumu bireyler arasında sosyal, siyasi ve ekonomik ilişkilerde karşılıklı olarak dürüstlüğü ve saygıyı ilke edinen; mesleki ahlak ve hakkaniyeti yanı sıra cömertlik ve güler yüzlülüğü de temel alan bir sistemdir. Ahilik yalnızca esnaf ve sanatkâra değil, halka da her zaman güven veren bir kurumdur (Kart, 2017: 45-46). 
Ahilik Anadolu'da politik ve ekonomik durumlardan dolayı şekillenmeye başlamıştır (Günay, 2003: 13). Ahilik teşkilatının kuruluş sebepleri şu şekilde sıralanabilir (Ecer, 2001: 12):

- Asya'dan göç eden esnaf ve sanatkârlara iş bulunması,

- Yerli sanatkârlar ile tüccarların rekabet edebilmesi,

- Sanat ahlakının yerleştirilmesi,

- Türk milletinin ekonomik yönden bağımsız hale getirilmesi,

- Yabancı saldırılara karşı devlet güçlerinin yanında yer alınması,

- Türklük şuurunun ve milli heyecanın ayakta tutulması,

- Türklerin yerleşik hayata geçmeleri.

Ahiliğin temel amacı, yurtlarını terk edip Anadolu'ya gelen Türklerin, kendi sanat ve ticaretlerine, yeni bir kültür ve çalışma alanı oluşturmalarıdır. Ahilik, devlet otoritesi dışında kurulmuş olsa da, devletin ve milletin iyiliği için çalışmaktadır (Durak ve Yücel, 2010:151-168). Ahilik, insanları çalışmaya teşvik eder ve bir meslek alanında uzman olmaları, kimseye muhtaç olmadan yaşamaları konusunda yön verir. Ahiliğin hedefi halk ile esnafı ortak bir noktada birleştirerek, gerekli güvenin sağlanmasıdır (Kantarcı, 2007: 66-71). İ̧ ve meslek hayatındaki ahlak kuralları, Ahilik'te, kabul edilmesi mecburi kurallar haline gelmiştir (Can, 2003:9). Meslek içi ilişkilerin düzenlendiği, örf ve adetlere göre dini esaslara dayanan Ahilik, saygı ve sevginin devamlı olduğu bir teşkilattır. Mutlak otoriteye bağlı olan Ahiliğin, insan yaşamını düzenlediği ve insanları kötü akımlardan kurtardığı söylenebilir (Bayram, 2012: 86). Ahiliğin temelinin, temel ahlaki değerler, fütüvvetnameler, dini kurallar, örf ve adetler etrafında toplandığı görülmektedir. Bazı temel ilkeleri şu şekilde sıralanabilir (Aslanderen, 2016: 11):

- İyi huylu ve güzel ahlaklı olmak,

- Gözü, gönlü, kalbi tok olmak,

- Ayıp ve kusurları, örtmek gizlemek, affetmek,

- Daima iyi komşulukta bulunmak, komşunun eza ve cahilliğine sabretmek,

- Hakka, hukuka, hakkaniyete riayet etmek,

- Kötü söz ve hareketlerden sakınmak,

- İçi-dışı, özü-sözü bir olmak,

- Sır tutmak, sırları açığa vurmamak,

- Aza kanaat, çoğa şükretmek ve dağıtmak,

- Helal kazanç sahibi olmak,

- Doğru ve dürüst olmak,

- Cömert olmak,

- Tevazu sahibi olmak,

- Alçak gönüllü olmak,

- Merhametli olmak,

- Bencil olmamak,

- İyi huylarını geliştirmek,

- Misafirleri sevmek, 
- Nasihatleri ile insanları iyiye yöneltmek,

- Dindar olmak,

- Hayâ sahibi olmak,

- Yalan söylememek,

- Dedikodu yapmamak,

- Kusur aramak yerine kusurları örtmek,

- İçki içmemek,

- Zina yapmamak,

- Kimseye karşı kin ve düşmanlık beslememek,

- Büyüklere karşı hürmetkâr küçüklere karşı şefkatli olmak,

- Nefsine hâkim olmak,

- Eline, diline sahip olmak,

- Hirs sahibi olmamaktır.

Bunların dışında, Ahi geleneğinde iş değiştirme hoş karşılanmazdı (Akbaş, 2000: 61-62). Ahilikte "doğrulukta yapılmayan iş, bereket getirmez, getirse de bu sürekli olmaz"” anlayışı hâkimdir (Aslanderen, 2016: 14). Ahi geleneğinde tembellik yasaktır. Ayrıca fiyatta ve ürünlerde bir standart sağlanmıştır. Kalite kontrolleri esnaf şeyhi tarafından yapılır kalitesiz mal üretip satan esnafların pabucu dama atılarak halka sergilenirdi (Akbaş, 2000: 62). Ahiliğin resmi olmayan yani fütüvvetnamelerinde yer almayan çalışma ahlakı ilkeleri ise şu şekilde sıralanabilir (Gelici, 2007: 65-69):

- Ahinin işi ve sanatı olmalıdır.

- Ahi birkaç iş veya sanatla değil, yeteneklerine uygun bir iş veya sanatla uğraşmalıdır.

- Ahi doğru olmalı, emeğinden fazlasını kazanmaya çalışmamalıdır.

- Ahi, gelenek ve otoriteye bağlı olmalıdır.

- Ahi, dayanışmacı olmalıdır.

- Ahiler, yanlarında çalışanlara emekleri sömürülecek varlıklar olarak değil, yetiştirilecek ve ileride iş yeri temin edilecek insan olarak bakar.

- Ahilik, mal biriktirme peşinde koşan ve istismarcı ticarete karşıdır.

- Ahi kardeşini, kendine tercih edendir.

- Ahinin 18 dirhem gümüşten fazla dünyalığı olmamalıdır.

- Ahi, sınırsız ve aşırı mal biriktirme hırsına sahip olmaz.

Ahilik teşkilâtı, toplumsal değerleri bireyin içselleştirmesinde ve davranışa dönüştürmesinde önemli rol oynamış tarihe mal olmuş bir meslekî sivil toplum kuruluşudur. Ahilik, bir meslek örgütü olduğu kadar, getirmiş olduğu ahlâkî öğretilerle birlikte, aynı zamanda ahlâkî değerlerin günlük hayatın bütün sahalarında yaşanmasını hedeflemiş yaygın bir ahlâk eğitim merkezi mahiyetindedir. Ahilik, bireye kendini tanıma yollarını göstererek, fıtratını korumasını ve bireyin yaşamına evrensel ahlâk değerlerini hâkim kılmayı hedef edinen bir kurumdur (Kaya, 2013: 41) .

Toplumsal yaşamın önemli bir kısmını oluşturan ve mesleki yaşamda karşılaşılan sorunların önemli bir kısmı, meslek insanlarındaki değer sorunlarından kaynaklanmaktadır. İşçi, işveren, üretici, pazarlamacı, reklamcı, esnaf, tüketici gibi meslek yaşamının farklı taraflarının sahip olduğu değerlerin ve bu değerlerin 
bileşkesinden oluşan mesleki yaşamının ilke ve prensipleri, karşılaşılan çok yönlü sorunların önemli bir kısmına neden oluşturmaktadır (Yeşil, 2011: 1117). Karşılaşılan bu sorunların çözümünde Ahilik değerlerinin benimsenmesinin önemli bir rol oynayacağı muhakkaktır.

Geçmişimizde var olan birçok organizasyon gibi Ahilik yapısı ve onun bir tür içeriği olan Fütüvvetnameler geçmişte uygulanmış, kısmen nostaljik bir yönü öne çıkarılan fakat bugün için canlılığı olabilecek ve bu yönleri ile örnek teşkil edecek yapılar olarak maalesef görülmemektedir. Aksine, bu yapılar genelde tarihi ve folklorik yapılar olarak ele alınmakta ve onların içeriklerine olması gerektiği derecede ehemmiyet verilmemektedir. Oysa Ahilik ve Fütüvvet yapıları içinde, bugün ve yarın da kullanılabilecek teorik ve pratik yönleri olan önemli değerler mevcuttur. Mesleki hayat içinde meslek ahlakı denen konu her devirde olduğu gibi bugün de büyük önem taşımaktadır. Ahilik yapısı içinde var olan yamak-çırak-kalfa-usta hiyerarşisi, bugün Mesleki Yeterlilik Kurumu çatısı altında uygulanmaya çalışılan sekiz basamaklı yeterliliklere benzetmektedir (Erken, 2019: 1).

Ahilik kurumunda çalışanların yetiştirilmesine ve iletişimine büyük önem verilmiştir. Uzun süreli istihdam, yavaş değerlendirme, terfi ve uzmanlaşmaya dayalı iş bölümü esastır. Diğer taraftan ahilikte danışma, soru sorma ve herkesin fikrine saygı vardır. Zaviyelerde iş eğitimi dışında fen bilimleri, sosyal bilimler, güzel sanatlar gibi pek çok alanda eğitim verilmesi bugün Japon yönetiminde görülen iş ve sosyal hayatın bütünleştirilmesinin bundan yüzyıllar önce Ahi örgütlenmesinde yaşandığını göstermektedir (İrmiş, 1998: 41). Ahilik kültüründe yer alan bir dizi temel ilke ve prensiplerin bugün bilginin gelişim ve paylaşımında kullanılan modern yöntemlerle çok benzerlikler arz ettiği ortadadır (Doğan, 2011: 77).

21. yüzyılda ön plana çıkan, yönetimde ve çalışma hayatında etik, sosyal sorumluluk, kalite, müşteri memnuniyeti, şeffaflık, işyerinde yönetime katılma, mentorluk gibi kavramlar ile odalar ve borsalar gibi mesleki kuruluşlarla Ahilik teşkilatı arasında önemli paralellikler söz konusudur. Günümüz modern çalışma hayatında müşteri odaklılık ve bireyi ön planda tutma önemli bir rekabet aracı haline gelmiştir. Ahilikte ise, müşteriyi veli nimet bilme ve üretici, tüketici ve yönetilen ve yönetici olarak "insan merkezli" yaklaşım vardır (Durak ve Yücel 2010: 165). Ahilikte kaliteli ve standart üretim için geliştirilen usul ve kurallar bugünkü Toplam Kalite Yönetimi ve oto kontrol sisteminin ilk hayata geçirilişidir. Bir bakıma TSE kurumunun o tarihlerdeki uygulamasıdır (Demir, 2001: 82) .

Günümüzde çalışma yaşamında yaşanan sorunlara yönelik çözüm önerileri sunan bu yöntem ve tekniklerinin çoğunun Ahilik müessesinin ortaya koyduğu değerlerin özeti olduğu görülmektedir. Öyle ki, çoğu eserde ortak olan konu olan hayata pozitif bakmak, bardağın dolu tarafını görmek, insanlara güler yüz göstermek, çevremizdekileri sevmek, saymak vb. ifadeler sanki yeni keşfedilmiş gibi sunulmaktadır. Aslında bu ve benzeri değerler yüzyıllardır Türk toplumunda Ahilik müessesi ile kökleşmiş ve günümüze kadar gelmiştir (Kavi, 2015: 104).

Bu çalışma ile yukarıda sıralanan ilkeler doğrultusunda, Ahilik değerlerinin Ahiliğin merkezi olan Kırşehir'de, esnaf ve sanatkârlalar tarafından ne derecede benimsendiği ve uygulandığı belirlenmeye çalışılacaktır.

\section{Yöntem}

Bu araştırmanın temel amacl; Kırşehir ilindeki esnaf ve sanatkârların Ahilik değerlerine sahip olma durumlarının belirlenmesidir. Araştırma, nicel araştırma deseni kullanılan, tanımlayıı tipte bir çalışmadır. Çalışmanın evrenini, Kırşehir il merkezinde bulunan esnaf/sanatkârlar ile bu işyerlerinde çalışanlar oluşturmaktadır. Araştırmada verilerin toplanabilmesi için basit rastgele, kolayda örnekleme yöntemi kullanılarak, araştırmaya katılmayı kabul eden farklı meslek gruplarından toplam 310 kişiye ulaşılarak anket uygulanmıştır. Araştırmada esnaf ve sanatkârlardan komşusu olan bir başka esnaf/ sanatkârı; çalışanlardan ise çalıştığı iş yerinin sahibini değerlendirmesi istenmiştir.

Verilerin toplanmasında sosyo-demografik bilgiler formu ile Yeşil ve Aslanderen (2016) tarafından geliştirilen Ahilik Değerler Ölçeği (ADÖ) kullanılmıştır. Söz konusu ölçeğin orijinali 32 maddeden oluşmakta ve sorular; 0-Kesinlikle katılmıyorum/4- Kesinlikle katılıyorum şeklinde puanlanmaktadır. Ancak bu çalışmada 
ölçek soruları; 1-Kesinlikle katılmıyorum/5-Kesinlikle katılıyorum şekline dönüştürülmüştür. Ölçek dört alt boyuttan meydana gelmekte olup bu boyutlar;

- Mesleki Standart Faktörü (MSF) 10 soru,

- Insanlarla ílişkiler Faktörü (iif) 9 soru,

- Mesleki Gelişim-Eğitim Faktörü (MG/EF) 7 soru,

- Zaafiyet Faktörü (ZF) 6 sorudan meydana gelmektedir.

Zaafiyet faktörüne ilişkin 6 soru ters kodlanmıştır. Ters kodlanan ve olumsuz ifadeler içeren bu sorular analiz aşamasında olumlu ifadelere döndürülerek değerlendirilmiştir. Ölçeğin Cronbach Alpha Güvenilirlik katsayısı 0,911 olarak hesaplanmıştır.

Araştırmada elde edilen veriler, bilgisayar ortamına aktarılarak ilk etapta veri kontrolü yapılmış ve hatalı veriler düzenlenmiştir. İstatistiksel analizler SPSS 20.0 programında yapılmıştır. ADÖ ile toplanan verilerin normal dağılıma uyup uymadığını test etmek için Kolmogorov-Simirnov testi yapılmış ve verilerin normal dağıııma uymadığı görülmüştür. Bu nedenle veriler üzerinde Mann Whitney U testi, KW Varyans analizi ve Sperman Korelasyon analizi testleri yapılımıştır. Ayrıca tanımlayııı istatistikler hesaplanmıştır. Ayrıca ölçeğin geçerliliğini test etmek için Açımlayıcı Faktör Analizi yöntemi kullanılııştır.

Tablo 1'de görüldüğü gibi, Ahilik Değerler Ölçeğine ilişkin verilerin faktör analizine uygun olup olamadığının anlaşıması için ise KMO ve Bartlett testi uygulanmıştır. Test sonuçlarına göre KMO katsayısı 0,958 ve $p<0,01$ olduğundan, verilerin faktör analizi için uygun olduğu sonucuna varılmıştır.

Tablo 1. Kullanılan Ölçeğe İlişkin KMO ve Bartlett Testi Sonuçları

\begin{tabular}{|l|l|c|}
\hline \multicolumn{2}{|l|}{ KMO } & 0,958 \\
\hline \multirow{3}{*}{ Bartlett testi } & Approx. Chi-Square & 8,013 \\
\cline { 2 - 3 } & Serbestlik Derecesi & 496 \\
\cline { 2 - 3 } & $\mathrm{p}$ & 0,000 \\
\hline
\end{tabular}

Tablo 2'de görüldüğü gibi, yapılan analiz sonucunda verilerin ölçeğin orijinalindeki gibi dört faktör altında toplanmış ve dört faktörün açıkladığı birikimli varyans miktarı, toplam varyansın \%67,248'ini oluşturmaktadır.

Tablo 2. Faktörlerin Öz Değerleri ve Varyans Açıklama Yüzdeleri

\begin{tabular}{|c|c|c|c|c|c|c|c|c|c|}
\hline \multirow{2}{*}{$\frac{\frac{\bar{d}}{\bar{\Phi}}}{\bar{\Phi}}$} & \multicolumn{3}{|c|}{ Başlangıç Özdeğerleri } & \multicolumn{3}{|c|}{$\begin{array}{c}\text { Türetilen Kareli Ağırlıklar } \\
\text { Toplamı }\end{array}$} & \multicolumn{3}{|c|}{$\begin{array}{l}\text { Rotasyon Sonucu Kareli } \\
\text { Ağırlıklar Toplamı }\end{array}$} \\
\hline & Toplam & $\begin{array}{l}\text { Varyans } \\
\quad \%\end{array}$ & $\begin{array}{l}\text { Yığılımlı } \\
\%\end{array}$ & Toplam & Varyans \% & Yığılımlı \% & Toplam & Varyans \% & Yığılımlı \% \\
\hline 1 & 15,998 & 49,993 & 49,993 & 15,998 & 49,993 & 49,9 & 5,794 & 18, & 18,108 \\
\hline 2 & 2,836 & 8,863 & 58,856 & 2,836 & 8,863 & 58,856 & 5,660 & 17,688 & 35,796 \\
\hline 3 & 1,679 & 5,247 & 64,102 & 1,679 & 5,247 & 64,102 & 5,201 & 16,254 & 52,049 \\
\hline 4 & 1,006 & 3,145 & 67,248 & 1,006 & 3,145 & 67,248 & 4,863 & 15,198 & 67,248 \\
\hline
\end{tabular}

Tablo 3'te döndürülmüş faktör matrisine ilişkin bulgular yer almaktadır. Analiz sonucunda araştırmada kullanılan ölçeğin geçerli bir ölçek olduğu, faktörlerin ve faktörler altında yer alan soruların orijinal ölçekle uyumlu olduğu belirlenmiştir. 
Tablo 3. Döndürülmüş Faktör Matrisi

\begin{tabular}{|c|c|c|c|c|}
\hline & \multicolumn{4}{|c|}{ Bileşenler } \\
\hline Ölçek Maddeleri & 1 & 2 & 3 & 4 \\
\hline Hilesiz ve kaliteli mal üretip, satmaya özen gösterirler. & 0,787 & & & \\
\hline Meslekleriyle ilgili kanun ve kurallara uygun davranırlar. & 0,756 & & & \\
\hline Yapacakları işi savsaklamazlar gününde teslim ederler. & 0,755 & & & \\
\hline Müşterilerin haklarını korur, haklarını yemezler. & 0,808 & & & \\
\hline Rızkını kazandığı mesleğe saygı duyar ve önem verirler. & 0,629 & & & \\
\hline Mesleklerini özenerek yaparlar. & 0,664 & & & \\
\hline Yanlarında çalışanlara karşı sorumluluklarını bilirler ve haklarını gözetirler. & 0,586 & & & \\
\hline İnsanları zengin-yoksul, güçlü-zayıf olarak ayırmazlar, eşit davranırlar. & 0,527 & & & \\
\hline Müşteri ve komşu esnaflara kin gütmez, kıskançlık etmezler. & 0,677 & & & \\
\hline Vergilerini zamanında ve tam verirler. & 0,371 & & & \\
\hline $\begin{array}{l}\text { Komşu esnaf ve sanatkârlarında elde etmesini ister, gerekirse müşterileri } \\
\text { yönlendirir. }\end{array}$ & & 0,690 & & \\
\hline Diğer esnaf ve sanatkârlarla dayanışma içerisinde çalışırlar. & & 0,686 & & \\
\hline Fedakâr insanlardır, mal, emek ve zamanlarından fedakârlık ederler. & & 0,636 & & \\
\hline Alışverişleriyle ilgili hata ve kusurları öncelikle kendilerinde ararlar. & & 0,529 & & \\
\hline Bela ve musibetlere karşı sabırlıdırlar. & & 0,634 & & \\
\hline Az kazanca kanaat ederler, çok kazanca şükrederler. & & 0,661 & & \\
\hline Müşterileri ve diğer esnaflarla ilgili sırları tutarlar, açığa vurmazlar. & & 0,603 & & \\
\hline Kötülük ve kendini bilmezliğe iyilikle karşılık verirler. & & 0,537 & & \\
\hline Müşterilere ve diğer komşu esnaflara karşı kötü söz ve hareketlerden sakınırlar. & & 0,528 & & \\
\hline $\begin{array}{l}\text { Meslekleri ile ilgili gelişmeleri medya ve diğer kitle iletişim araçlarında takip } \\
\text { ederler. }\end{array}$ & & & & 0,624 \\
\hline $\begin{array}{l}\text { Yanlarında çalışan elemanların mesleğini öğrenmesi ve eğitilmeleri için } \\
\text { düzenlenen kurs, seminer ve sertifika programlarına gönderirler. }\end{array}$ & & & & 0,679 \\
\hline İş güvenliğine önem verirler, gerekli tedbirleri alırlar. & & & & 0,669 \\
\hline Ürünlerine ve çalışma şartlarında hijyene önem verirler. & & & & 0,583 \\
\hline Eğitime büyük önem verirler, ihtiyaç sahibi öğrencilere yardımda bulunurlar. & & & & 0,567 \\
\hline Yanlarında çalışanların sosyal sigorta primlerini zamanında yerine getirirler. & & & & 0,665 \\
\hline $\begin{array}{l}\text { Mesleki fuarlara ya da düzenlenen eğitim seminerlerine katılarak mesleklerinde } \\
\text { kendilerini geliştirmeye çalışırlar. }\end{array}$ & & & & 0,757 \\
\hline Müşteri ve komşu esnaflarla ilgili dedikodu yapar, iftira atarlar. & & & 0,777 & \\
\hline Mal ve para kazanma konusunda açgözlü davranırlar. & & & 0,842 & \\
\hline Dünyaya ait şeylerle övünürler, böbürlenirler. & & & 0,820 & \\
\hline Malını pahalanınca satmak için saklarlar. & & & 0,819 & \\
\hline Mal biriktirme hırsıyla hareket eder, sürekli birikim yapmayı amaçlarlar. & & & 0,815 & \\
\hline Malını överek müşteriyi aldatmaya çalışırlar. & & & 0,797 & \\
\hline
\end{tabular}

\section{Bulgular}

Araştırmadan elde edilen bulgular tablolar halinde aşağıda sunulmuştur.

Tablo 4'te görüldüğü üzere araştırmaya katılımcıların \%49,4'ü (153) erkek, \%50,6'sı (157) kadındır. Öğrenim durumu açısından incelendiğinde; \%10,3'ü (32) ilkokul mezunu, \%10,3'ü (32) ortaokul mezunu, $\% 35,8{ }^{\prime} \mathrm{i}$ (111) lise mezunu, \%43,5'i (135) üniversite mezunudur. Ortalama aylık gelire bakıldığında; \%48,1'i (149) $1.000 \mathrm{TL}$ ile $2.000 \mathrm{TL}$ arasında, \%24,8'i (77) $2.001 \mathrm{TL}$ ile $3.500 \mathrm{TL}$ arasında, \%14,2'si (44) $3.501 \mathrm{TL}$ ile $5.000 \mathrm{TL}$ arasında, \%12,9'u (40) $5.000 \mathrm{TL}$ den daha fazla gelire sahiptir. Görev açısından bakıldığında; \%40,6 (126) işyeri sahibi, \%6,1 (19) işyeri yöneticisi ve \%53,3'üu (165) çalışanlardan oluşmaktadır. Katılımcıların yaşlarına bakıldığında \%39,4'ü (122) $20-29$ yaş aralığında ve \%15,8'i (49) ise $50+$ yaş grubundadır. 
Tablo 4. Katılımcıların Sosyo-Demografik Özellikleri

\begin{tabular}{|c|c|c|c|c|c|}
\hline Öğrenim Düzeyi & $\mathbf{n}$ & (\%) & Aylık Gelir & $n$ & (\%) \\
\hline İlkokul Mezunu & 32 & 10,3 & $1.000-2.000$ & 149 & 48,1 \\
\hline Ortaokul Mezunu & 32 & 10,3 & $2,001-3.500$ & 77 & 24,8 \\
\hline Lise Mezunu & 111 & 35,8 & $3.501-5.000$ & 44 & 14,2 \\
\hline Üniversite Mezunu & 135 & 43,5 & 5.001 TL'den çok & 40 & 12,9 \\
\hline Görev & $\mathbf{n}$ & (\%) & Yaş & $\mathbf{n}$ & (\%) \\
\hline İş yeri sahibi & 126 & 40,6 & $20-29$ & 122 & 39,4 \\
\hline İş yeri yöneticisi & 19 & 6,1 & $30-39$ & 78 & 25,2 \\
\hline Çalışan & 165 & 53,3 & $40-49$ & 61 & 19,7 \\
\hline & & & $50+$ & 49 & 15,8 \\
\hline Cinsiyet & $\mathbf{n}$ & $(\%)$ & \multirow[t]{3}{*}{ Toplam } & \multirow[t]{3}{*}{310} & \multirow[t]{3}{*}{100} \\
\hline Erkek & 153 & 49,4 & & & \\
\hline Kadın & 157 & 50,6 & & & \\
\hline
\end{tabular}

Tablo 5'te görüldüğü gibi ölçeğin Meslek Standartları Faktöründe 10 soru yer almaktadır. Bu sorulara verilen cevapların aritmetik ortalaması 3,36 olarak hesaplanmıştır. Sorulara verilen cevaplar incelendiğinde en yüksek puanın "rızkını kazandığı mesleğe saygı duyar ve önem verirler" (Ort. $=3,58)$ sorusuna, en düşük puanın ise "müşteri ve komşu esnaflara kin gütmez, kıskançlık etmezler" $(O r t .=3,04)$ sorusuna verildiği görülmektedir.

Tablo 5. Ahilik Değerleri Ölçeğinde Yer Alan Sorulara Verilen Cevaplara illişkin Tanımlayıcı İstatistikler (Meslek Standartları Faktörü)

\begin{tabular}{|l|c|c|}
\hline Mesleki Standartlar Faktörü & Ort. & Std. Sap \\
\hline Hilesiz ve kaliteli mal üretip, satmaya özen gösterirler. & 3,49 & 1,233 \\
Meslekleriyle ilgili kanun ve kurallara uygun davranırlar. & 3,46 & 1,221 \\
Yapacakları işi savsaklamazlar gününde teslim ederler. & 3,39 & 1,287 \\
Müşterilerin haklarını korur, haklarını yemezler. & 3,31 & 1,351 \\
Rızkını kazandı̆̆ı mesleğe saygı duyar ve önem verirler. & 3,58 & 1,203 \\
Mesleklerini özenerek yaparlar. & 3,40 & 1,249 \\
Yanlarında çalışanlara karşı sorumluluklarını bilirler ve haklarını gözetirler. & 3,34 & 1,235 \\
Innsanları zengin-yoksul, güçlü-zayıf olarak ayırmazlar, eşit davranırlar. & 3,17 & 1,431 \\
Müşteri ve komşu esnaflara kin gütmez, kıskançlık etmezler. & 3,04 & 1,421 \\
Vergileri zamanında ve tam verirler. & 3,46 & 1,105 \\
\hline Toplam & $\mathbf{3 , 3 6}$ & $\mathbf{1 , 0 1}$ \\
\hline
\end{tabular}

Tablo 6'da görüldüğü gibi, İnsanlarla i̇lişkiler Faktöründe 9 soru yer almaktadır. Bu sorulara verilen cevapların aritmetik ortalaması 3,15'tir. Sorulara verilen cevaplar incelendiğinde en yüksek puanın "fedakâr insanlardır, mal, emek ve zamanlarından fedakârlık ederler" (Ort.=3,28) sorusuna, en düşük puanın ise "alışverişleriyle ilgili hata ve kusurları öncelikle kendilerinde ararlar" (Ort. $=3,03)$ sorusuna verildiği görülmektedir. 
Tablo 6. Ahilik Değerleri Ölçeğinde Yer Alan Sorulara Verilen Cevaplara İlişkin Tanımlayıcı İstatistikler (Insanlarla Illişkiler Faktörü)

\begin{tabular}{|l|c|c|}
\hline Insanlarla iliş̧iler Faktörü & Ort. & Std. Sap \\
\hline Komşu esnaf ve sanatkârlarında elde etmesini ister, gerekirse müşterileri & 3,18 & 1,354 \\
yönlendirir. & 3,22 & 1,258 \\
Diğer esnaf ve sanatkârlarla dayanışma içerisinde çalışıllar. & 3,28 & 1,295 \\
Fedakâr insanlardır, mal, emek ve zamanlarından fedakârlık ederler. & 3,03 & 1,377 \\
Alışverişleriyle ilgili hata ve kusurları öncelikle kendilerinde ararlar. & 3,13 & 1,344 \\
Bela ve musibetlere karşı sabırlıdırlar. & 3,15 & 1,453 \\
Az kazanca kanaat ederler, çok kazanca şükrederler. & 3,09 & 1,328 \\
Müşterileri ve diğer esnaflarla ilgili sırları tutarlar, açı̆̆a vurmazlar. & 3,08 & 1,292 \\
Kötülük ve kendini bilmezliğe iyilikle karşılık verirler. & 3,22 & 1,253 \\
Müşterilere ve diğer komşu esnaflara karşı̈ıötü söz ve hareketlerden sakınırlar. & $\mathbf{3 , 1 5}$ & $\mathbf{1 , 0 8}$ \\
\hline Toplam &
\end{tabular}

Tablo 7'de görüldüğü gibi, Mesleki Gelişim/Eğitim Faktörü 8 sorudan oluşmaktadır. Bu sorulara verilen cevapların aritmetik ortalaması 3,17 olarak hesaplanmıştır. Sorulara verilen cevaplar incelendiğinde en yüksek puanın "meslekleri ile ilgili gelişmeleri medya ve diğer kitle iletişim araçlarında takip ederler" $(O r t .=3,35)$ sorusuna, en düşük puanın ise "eğitime büyük önem verirler, ihtiyaç sahibi öğrencilere yardımda bulunurlar" (Ort.=3,03) sorusuna verildiği görülmektedir.

Tablo 7. Ahilik Değerleri Ölçeğinde Yer Alan Sorulara Verilen Cevaplara İlişkin Tanımlayıcı İstatistikler (Mesleki Gelişim/Eğitim Faktörü)

\begin{tabular}{|l|c|c|}
\hline Mesleki Gelişim/Eğitim Faktörü & Ort. & Std. Sap \\
\hline Meslekleri ile ilgili gelişmeleri medya ve diğer kitle iletişim araçlarında takip & 3,35 & 1,232 \\
ederler. & 3,08 & 1,204 \\
Yanlarında çalışan elemanların mesleğini öğrenmesi ve eğitilmeleri için & 3,24 & 1,262 \\
düzenlenen kurs, seminer ve sertifika programlarına gönderirler. & 3,13 & 1,400 \\
iş güvenliğine önem verirler, gerekli tedbirleri alırlar. & 3,03 & 1,261 \\
Ürünlerine ve çalışma şartlarında hijyene önem verirler. & 3,24 & 1,170 \\
Eğitime büyük önem verirler, ihtiyaç sahibi öğrencilere yardımda bulunurlar. & & \\
Yanlarında çalışanların sosyal sigorta primlerini zamanında yerine getirirler. & & \\
Mesleki fuarlara ya da düzenlenen eğitim seminerlerine katılarak mesleklerinde & 3,13 & 1,206 \\
kendilerini geliştirmeye çalışıllar. & $\mathbf{3 , 1 7}$ & $\mathbf{0 , 9 6}$ \\
\hline Toplam &
\end{tabular}

Tablo 8' de görüldüğü gibi, Zaafiyet Faktöründe 6 soru yer almaktadır. Bu sorulara verilen cevapların aritmetik ortalaması 3,13'tir. Sorulara verilen cevaplar incelendiğinde en yüksek puanın "müşteri ve komşu esnaflarla ilgili dedikodu yapmaz, iftira atmaz" $($ Ort.=3,32) sorusuna, en düşük puanın ise "mal biriktirme hırsıyla hareket etmez, sürekli birikim yapmayı amaçlamaz" ve "malını överek müşteriyi aldatmaya çalışmaz" $(2,97)$ sorularına verildiği görülmektedir. 
Esnaf ve Sanatkârların Ahilik Değerlerine Sahip Olma Durumlarının Bazı Değişkenler Açısından Belirlenmesi: Kırşehir Örneği

Tablo 8. Ahilik Değerleri Ölçeğinde Yer Alan Sorulara Verilen Cevaplara İlişkin Tanımlayıcı İstatistikler (Zaafiyet Faktörü)

\begin{tabular}{|l|c|c|}
\hline Zaafiyet Faktörü & Ort. & Std. Sap \\
\hline Müşteri ve komşu esnaflarla ilgili dedikodu yapmaz, iftira atmaz. & 3,32 & 1,339 \\
Mal ve para kazanma konusunda açgözlü davranmaz. & 3,10 & 1,366 \\
Dünyaya ait şeylerle övünmez, böbürlenmez & 3,22 & 1,395 \\
Malını pahalanınca satmak için saklamaz & 3,25 & 1,362 \\
Mal biriktirme hırsıyla hareket etmez, sürekli birikim yapmayı amaçlamaz & 2,97 & 1,393 \\
Malını överek müşteriyi aldatmaya çalışmaz & 2,97 & 1,469 \\
\hline Toplam & 3,13 & 1,19 \\
\hline
\end{tabular}

Ölçek puanlarının sosyo-demografik değişkenler açısından farklılık gösterip göstermediğinin test edilmesi amacıyla, verilerin normal dağılıma uymaması (Tablo 9) nedeniyle ikili karşılaştırmalarda MannWhitney U testi, çoklu karşılaştırmalarda ise Kruskal Wallis Varyans Analizi kullanılmıştır. Bulgular aşağıda tablolar halinde gösterilmektedir.

Tablo 9. Normallik Testi

\begin{tabular}{|l|c|c|c|c|c|c|}
\hline \multirow{2}{*}{} & \multicolumn{3}{|c|}{ Kolmogorov-Smirnov } & \multicolumn{3}{c|}{ Shapiro-Wilk } \\
\cline { 2 - 7 } & İstatistik & $\mathrm{df}$ & $\mathrm{p}$ & İstatistik & $\mathrm{df}$ & $\mathrm{p}$ \\
\hline Mesleki standartlar faktörü & 0,063 & 310 & 0,004 & 0,972 & 310 & 0,000 \\
İnsanlarla ilişkiler faktörü & 0,076 & 310 & 0,000 & 0,968 & 310 & 0,000 \\
Mesleki gelişim faktörü & 0,064 & 310 & 0,004 & 0,983 & 310 & 0,001 \\
Zaafiyet faktörü & 0,092 & 310 & 0,000 & 0,948 & 310 & 0,000 \\
Ölçek Toplamı & 0,090 & 310 & 0,000 & 0,978 & 310 & 0,000 \\
\hline
\end{tabular}

Tablo 10 'da görüldüğü gibi araştırmada kullanılan ölçeğin alt faktör puanlarının ve ölçek toplam puanının cinsiyet açısından farklılık gösterip göstermediğini test etmek amacıyla yapılan Mann Whitney U testi sonucunda; mesleki standartlar faktörü, insanlarla ilişkiler faktörü, mesleki gelişim/eğitim faktörü ve ölçek toplam puanının istatistiksel açıdan anlamlı olduğu $(p<0,05)$, zaafiyet faktörünün ise istatistiksel açıdan anlamlı olmadığı $(p>0,05)$ görülmüştür.

Tablo 10. Ölçek Puanlarının Cinsiyet Açısından Karşılaştırılması

\begin{tabular}{|l|c|c|c|c|c|}
\hline & $\begin{array}{c}\text { Mesleki } \\
\text { Standartlar } \\
\text { Faktörü }\end{array}$ & $\begin{array}{c}\text { İnsanlara } \\
\text { ilişkiler } \\
\text { Faktörü }\end{array}$ & $\begin{array}{c}\text { Mesleki } \\
\text { Gelişim/Eğitim } \\
\text { Faktörü }\end{array}$ & $\begin{array}{c}\text { Zaafiyet } \\
\text { Faktörü }\end{array}$ & $\begin{array}{c}\text { Ölçek } \\
\text { Toplam } \\
\text { Puanı }\end{array}$ \\
\hline Erkek $(\mathrm{n}=152)$ & 168,89 & 170,32 & 169,88 & 164,47 & 169,24 \\
Kadın ( $\mathrm{n}=158)$ & 142,62 & 141,25 & 141,67 & 146,87 & 142,28 \\
\hline Mann-Whitney U & 9972 & 9756 & 9823 & 10644,0 & 9919 \\
& $-2,582$ & $-2,857$ & $-2,773$ & $-1,733$ & $-2,648$ \\
& $\mathbf{0 , 0 1 0}$ & $\mathbf{0 , 0 0 4}$ & $\mathbf{0 , 0 0 6}$ &, 083 & $\mathbf{0 , 0 0 8}$ \\
\hline
\end{tabular}

Tablo 11'de görüldüğü gibi ölçeğin alt faktör puanlarının ve ölçek toplam puanının öğrenim durumu, görev, yaş ve gelir açısından farklılık gösterip göstermediğinin tespit edilmesi amacıyla KW Varyans Analizi yöntemi kullanılmıştır. Yapılan analiz sonucunda faktör puanlarının ve ölçek toplam puanlarının öğrenim ve görev açısından farklıık gösterdiği, gelir açısından ise herhangi bir fakın olmadığı belirlenmiştir. Yaş değişkeni 
açısından bakıldığında ise mesleki standart faktörü, zaafiyet faktörü ve ölçek toplam puanının istatistiksel açıdan anlamlı olduğu, mesleki gelişim ve insanlarla ilişkiler faktörü açısından ise anlamlı bir fark olmadığı saptanmıştır.

Tablo 11. Ölçek Puanlarının Eğitim Durumu, Görev, Yaş ve Gelir Açısından Karşılaştırılması (Kruskal Wallis Varyans Analizi)

\begin{tabular}{|c|c|c|c|c|c|c|}
\hline Değişken & Değişken Sayıları & $\begin{array}{l}\text { Mesleki } \\
\text { Standartlar } \\
\text { Faktörü }\end{array}$ & $\begin{array}{c}\text { İnsanlara } \\
\text { İlişkiler } \\
\text { Faktörü }\end{array}$ & $\begin{array}{l}\text { Mesleki } \\
\text { Gelişim } \\
\text { Faktörü }\end{array}$ & $\begin{array}{l}\text { Zaafiyet } \\
\text { Faktörü }\end{array}$ & $\begin{array}{c}\text { Ölçek } \\
\text { Toplam } \\
\text { Puanı } \\
\end{array}$ \\
\hline \multirow{7}{*}{$\begin{array}{l}\text { Öğrenim } \\
\text { Durumu }\end{array}$} & & Ort. Rank & Ort. Rank & Ort. Rank & Ort. Rank & Ort. Rank \\
\hline & İlkokul $(n=32)$ & 218,50 & 213,11 & 201,83 & 212,23 & 221,64 \\
\hline & Ortaokul(n=32) & 160,44 & 157,03 & 166,33 & 160,56 & 161,52 \\
\hline & Lise $(n=111)$ & 157,03 & 158,28 & 155,99 & 155,11 & 156,43 \\
\hline & Üniv(n=135) & 138,14 & 139,19 & 141,55 & 141,17 & 137,63 \\
\hline & Chi-Square & 21,035 & 17,830 & 12,321 & 16,450 & 22,952 \\
\hline & $\mathrm{p}$ & 0,000 & 0,000 & 0,006 & 0,001 & 0,000 \\
\hline \multirow{5}{*}{ Görevi } & İşyeri sahibi $(n=126)$ & 191,26 & 185,31 & 182,65 & 185,38 & 190,27 \\
\hline & Yönetici (n=19) & 115,89 & 121,68 & 103,05 & 138,84 & 112,63 \\
\hline & Çalışan ( $n=165)$ & 132,75 & 136,63 & 140,81 & 134,60 & 133,88 \\
\hline & Chi-Square & 22,727 & 15,032 & 12,393 & 18,997 & 22,006 \\
\hline & $\mathrm{p}$ & 0,000 & 0,001 & 0,002 & 0,000 & 0,000 \\
\hline \multirow{6}{*}{ Yaş } & $20-29(n=122)$ & 135,82 & 145,17 & 146,44 & 144,81 & 142,37 \\
\hline & $30-39(n=78)$ & 152,35 & 144,74 & 148,11 & 131,64 & 144,30 \\
\hline & $40-49(n=61)$ & 174,70 & 175,06 & 166,89 & 181,81 & 174,42 \\
\hline & $50+(n=49)$ & 185,62 & 174,00 & 175,64 & 187,34 & 182,46 \\
\hline & Chi-Square & 14,338 & 7,747 & 5,251 & 18,785 & 10,987 \\
\hline & $\mathrm{p}$ & 0,002 & 0,052 & 0,154 & 0,000 & 0,012 \\
\hline \multirow{6}{*}{ Gelir } & $1.000-2.000(n=149)$ & 147,26 & 159,15 & 155,03 & 160,10 & 155,66 \\
\hline & $2.001-3.500(n=77)$ & 163,56 & 161,82 & 162,41 & 151,49 & 160,34 \\
\hline & $3.501-5.000(n=44)$ & 153,76 & 137,41 & 136,15 & 133,81 & 139,02 \\
\hline & $5.001+(n=40)$ & 172,60 & 149,64 & 165,24 & 169,95 & 163,70 \\
\hline & Chi-Square & 3,362 & 2,597 & 2,992 & 4,183 & 2,047 \\
\hline & $\mathrm{p}$ & 0,339 & 0,458 & 0,393 & 0,242 & 0,563 \\
\hline
\end{tabular}

\section{Sonuç ve Öneriler}

Bu çalışma ile Ahiliğin merkezi olan Kırşehir'de esnaf ve sanatkârların Ahilik değerlerinin benimseme ve iş hayatında uygulama durumları ortaya konulmaya çalışılmıştır. Çalışmadan elde edilen sonuçlar şu şekilde özetlenebilir:

Yapılan Açımlayıc Faktör Analizi ve güvenilirlik testi sonucunda araştırmada kullanılan Ahilik Değerleri Ölçeğinin geçerli ve güvenilir bir ölçek olduğu saptanmıştır.

Araştırmada katılımcıların çoğunluğunun üniversite mezunu olduğu, gelir düzeylerinin genel olarak 1000-2000 TL arasında değiştiği, 20-29 yaş grubunda oldukları ve kadınlardan oluştuğu gözlenmiştir. Bu sonuçlara bakarak; işletme sahiplerinin genel olarak üniversite mezunu, genç ve kadın personeli tercih ettiğini ve bu çalışanların genellikle asgari ücretle çalıştırıldığını söyleyebiliriz.

Ahilik Değerleri Ölçeği sorularına verilen cevapların genel aritmetik ortalaması 3,22 ve standart sapması 0,917 olarak hesaplanmıştır. Çalışma sonuçları incelendiğinde, esnaf ve sanatkârların Ahilik değerlerini benimseme noktasında olması gereken bir noktada olmadıkları ve Ahilik değerlerini yeterince benimsemedikleri görülmektedir. Aslanderen ve Yeşil (2016) tarafından aynı ölçek kullanılarak yapılan bir 
başka çalışma sonucunda da Kırşehir esnaf ve sanatkârların Ahilik değerlerine sahiplikleri konusunda sorunlar olduğu belirlenmiştir. Sonuçlar benzerlik göstermektedir.

Literatürde Ahilik değerlerinin esnaf ve sanatkârlar arasında yaşatılıp yaşatılmadı̆̆ının belirlenmesi amacıyla farklı ölçüm araçları kullanılarak, farklı illerde yapılan çalışmalar bulunmaktadır. Örneğin Zorlu ve arkadaşları (2012) tarafından Gümüşhane esnaf ve sanatkârları üzerinde yapılan bir çalışmada, Ahilik ve Ahiliğe ilişkin temel kavramların bilinilirlik düzeyinin ortalamanın altında kaldığı ve Ahilik yaklaşımının ortaya koyduğu davranışların günümüz işletmelerinde yeterince uygulanmadığı anlaşımıştır. Soysal ve Tan (2013) tarafından Kilis Sanayi İşletmelerindeki işletme sahip ve yöneticileri üzerinde yapılan çalışma sonucunda; genel anlamda uygulamada birtakım eksiklikler olsa da esnafının Ahilik geleneğini ifade eden ilkeleri uygulama çabası içerisinde oldukları belirlenmiştir. Akça (2003) tarafından yapılan Fethiye esnafının incelendiği bir başka çalışmada ise Ahiliğin bir teşkilat olarak ortadan kalkmış olmasına rağmen, bir anlayış ve ahlak olarak esnaf ve sanatkârının iş ve sosyal hayata ait tutum ve davranışlarına yön vermeye devam ettiği saptanmıştır. Bu bağlamda, esnafların sosyal çevreye, genel ahlaka, işe sosyal dayanışmaya, işyerlerinde çalışanlara ve ülke sorunlarına ait yaklaşımlarında Ahiliğe ait anlayışı büyük ölçüde yansıttıkları görülmüştür.

Ahilik Değerleri Ölçeğinde 4 alt faktör yer almakta olup bu faktörler; Mesleki Standart Faktörü (MSF), İnsanlarla iliş̧kiler Faktörü (iiF), Mesleki Gelişim-Eğitim Faktörü (MGEF) ve Zaafiyet Faktörüdür (ZF). Alt faktörlerin puan ortalaması incelendiğinde en yüksek puanın Meslek Standartları Faktörüne, en düşük puanın ise Zaafiyet Faktörüne verildiği görülmektedir. Aslanderen ve Yeşil (2016) tarafından yapılan çalışmada ise en yüksek puanın Mesleki Gelişim-Eğitim Faktörüne, en düşük puanın ise Zaafiyet Faktörüne verildiği görülmüştür. Her iki çalışmanın sonuçları birlikte değerlendirildiğinde esnaf ve sanatkârların zaafiyet noktasındaki sorunlarının, diğer faktörlere göre daha ön planda olduğu sonucuna varılmaktadır.

Cinsiyet açısından bakıldığında ZF boyutu açısından anlamlı bir fark görülmezken ( $p>0,05)$; MSF, iiF, MGEF VE Ölçek Toplam Puanı açısından farkın anlamlılık gösterdiği ve erkeklerin puan ortalamasının daha yüksek olduğu görülmektedir $(p<0,05)$. Sonuçlar Aslanderen ve Yeşil (2016) tarafından yapılan çalışmanın sonuçları ile benzerlik göstermektedir.

Öğrenim durumu açısından, katılımcıların öğrenim seviyesi artıkça tüm boyutlar açısından ölçek puanlarının düştüğü ve farkın istatistiksel açıdan anlamlı olduğu ortaya çıkmaktadır $(p<0,05)$. Bu durum, öğrenim seviyesi yüksek bireylerin beklenti seviyelerinin daha yüksek olması ve değerlendirme yaparken daha titiz davranmalarının bir sonucu olarak yorumlanabilir.

Katılımcıların görevleri açısından bakıldığında en düşük puanın yöneticiler tarafından ve daha sonra çalışanlar tarafından verildiği görülmektedir. Çalışanlar ve yöneticiler işyeri sahiplerini olumsuz olarak değerlendirirken, iş yeri sahiplerinin meslektaşlarına yönelik daha olumlu görüşleri olduğu görülmektedir.

Yaş açısından karşılaştırma yapıldığında sadece MSF açısından puanlar arasındaki farkın anlamlı oluğu $(p<0,05)$ ancak iiF, MGEF ve ZF puanı açısından farkın ise anlamlı olmadığı belirlenmiştir $(p>0,05)$.

Çalışma neticesinde; Kırşehir'de yaşayan ve araştırma kapsamında değerlendirilen esnaf ve sanatkârların, Ahilik değerlerini yeterince benimsemedikleri sonucuna ulaşılmıştır. Günümüzde de Ahilik değer ve ilkelerinin esnaf ve sanatkârlar tarafından benimsenmiş olması, iş hayatındaki ahlaki yozlaşmanın önüne geçilmesi açısından büyük bir önem taşımaktadır. Bu nedenle araştırma sonuçları doğrultusunda aşağıdaki öneriler geliştirilmiştir:

- Ahilik ilke ve standartlarının ülke genelinde, iş kurma ve geliştirme süreçlerinde bir adım olarak nitelendirilmesi ve tüm esnaf sanatkârların aynı eğitim programlarında geçişinin sağlanması,

- Ahilik ilkelerinin sadece bir örgütlenmeye ait değerler olarak algılanmaması ve çalışma ahlakı boyutunun öne çıkarılması amacıyla Kırşehir esnaf ve sanatkârlarına yönelik projelerin geliştirilmesi,

- Öğrenim düzeyi düşük olan esnaflara yönelik ahilik ekseninde çalışma ahlakı ve etik değerleri içeren tamamlayıcı, yaygın eğitim programları geliştirilmesi, 
- Kadın çalışanların çalışma hayatına katılımı artırılarak ilgili ilke ve değerleri benimsemelerine yönelik özel projelerin geliştirilmesi,

- Yaş ortalaması düşük olan esnaf ve sanatkarların ilgili ilke ve değerleri benimsemelerine yönelik oda ve kuruluşlarca motivasyon artırıcı uygulamaların (yılın esnafı, kaliteli esnaf vb.) geliştirilmesi,

- Kalite standartları belgesinin, esnaf ve sanatlarca da alınmasını teşvik edecek hukuki düzenlemelerin yapılması önerilmektedir.

\section{Son Notlar}

1. 22-24 Kasım 2018 tarihinde, Antalya'da gerçekleştirilen INGLOBE IV kongresinde sözlü bildiri olarak sunulmuş ve tam metin olarak yayımlanmış çalışmanın, yeniden düzenlenmiş halidir.

\section{Kaynaklar}

Akbaş, T. (2000). Sosyo-kültürel değerlerin Denizli sanayi kalkınmasındaki etkileri açısından Babadağ örneği. Gebze ileri Teknoloji Enstitüsü Sosyal Bilimler Enstitüsü, Yüksek Lisans Tezi, Gebze.

Akça, G. (2003). Ahilik geleneği ve günümüz Fethiye esnafı. Selçuk Üniversitesi Türkiyat Araştırmaları Dergisi, 14, 210219.

Akgündüz, M. (2014). Ticarî hayatta kardeşliği esas alan ahîlik teşkilatı. Harran Üniversitesi Ilahiyat Fakültesi Dergisi, 19(31), 9-17.

Arslanoğlu, i. (2004). Fütüvvetnameler ve bir fütüvvetname. 1. Ahilik Araştırmaları Sempozyumu, 12- 13 Ekim, Kırşehir.

Aslanderen, M. (2016). Esnaf ve sanatkârların ahlak değerlerine sahiplik düzeylerinin değerlendirilmesi (Kırşehir Örneği). Ahi Evran Üniversitesi Sosyal Bilimler Enstitüsü, Yüksek Lisans Tezi, Kırşehir.

Bakir, S. (2014). Bir eğitim kültürü olarak ahilik ve hülya taşın günümüz Bursa esnafında ahilik kültüründen izler adlı eseri. Ulus/ararası Türkçe Edebiyat Kültür Eğitim Dergisi, 3(1), 406-415.

Can, C. (2013). Ahilikten günümüze mesleki eğitimde çalışma ahlakı. Hasan Kalyoncu Üniversitesi Sosyal Bilimler Enstitüsü, Yüksek Lisans Tezi, Gaziantep.

Ceylan, K. (2013). Ahilik: Türk-islam medeniyetinde dünyevi ve uhrevi sistem. Ankara: T.C. Gümrük ve Ticaret Bakanlığı Kültür Yayınları.

Çağatay, N. (1989). Bir Türk kurumu olan ahilik. Ankara: Türk Tarih Kurumu Basımevi.

Çakmak, M. (2014). Ahiliğin tasavvufi temelleri ve ahilik fütüvvet ilişkisi. Hikmet Yurdu Düşünce-Yorum Sosyal Bilimler Araştırma Dergisi, 7(7), 13, 143-158.

Demir, M. (2004). Ahilik, Ahi Evren'i Veli ve Kırşehir'de ahilik kutlamaları. Cumhuriyet Üniversitesi Sosyal Bilimler Enstitüsü, Yüksek Lisans Tezi, Sivas.

Demir, G. (2001). Ahilik ve yükselen değerler. Görüş, Ocak Sayısı, 76-82.

Durak, I., \& Yücel, A. (2010). Ahiliğin sosyo-ekonomik yansımaları. Süleyman Demirel Üniversitesi iktisadi ve Idari Bilimler Fakültesi Dergisi, 15(2), 151-168.

Ecer, A. (2001). Ahmed Yesevi Dervişi Ahi Evren ve Kayseri'de ahilik. Erciyes Üniversitesi Sosyal Bilimler Enstitüsü Dergisi, 1(11), 47-64.

Erken, E. (2019). Ahilik donmuş bir yapı değildir; günümüze de uyarlanabilir. https://www.dunyabizim.com/mercekalti/ahilik-donmus-bir-yapi-degildir-gunumuze-de-uyarlanabilir-h25159.html (Erişim tarihi: 20.05.2019).

Gelici, M. (2007). Protestan iş ahlakı ile ahilik iş ahlakının karşılaştııılması. Marmara Üniversitesi Sosyal Bilimler Enstitüsü, Yüksek Lisans Tezi, İstanbul.

Günay, A. (2003). Ahilikte mesleki ve sosyal dayanışma. Sakarya Üniversitesi Sosyal Bilimler Enstitüsü, Yüksek Lisans Tezi, Sakarya.

Hulusi, D. (2011). Günümüz işletmeleri için ahilik kültüründen örtülü bilginin gelişim ve paylaşım örnekleri. Gümüşhane Üniversitesi Sosyal Bilimler Elektronik Dergisi, 4, 77-100.

İrmiş, A. (1998). Bir örgüt kültürü örneği olarak Türk milli kültüründe ahilik. Türk Yurdu, 18(126), 35-42. 
Kart, M. (2017). Değerler eğitiminde bir model olarak ahilik. Ahi Evran Üniversitesi Sosyal Bilimler Enstitüsü, Yüksek Lisans Tezi, Kırşehir.

Kavi, E. (2015). Ahilik kurumu ve günümüz çalışma yaşamındaki psikolojik sorunlara yönelik çözümler. HAK-iş Uluslararası Emek ve Toplum Dergisi, 4(8), 102-117.

Kaya, U. (2013). Değerler eğitiminde bir meslek teşkilâtı: Ahîlik. Değerler Eğitimi Dergisi, 11(26), 41-69.

Malkoç, E. (2016). Ahilik sistemi örgütlenme yapısının günümüz türkiye esnaf ve sanatkârları konfederasyonu ile karşılaştırılması. Karabük Üniversitesi Sosyal Bilimler Enstitüsü, Yüksek Lisans Tezi.

Soysal, A., \& Tan, M. (2013). Ahilik ilkelerinin günümüz işletmelerine yansıması: Kilis küçük sanayi sitesi işletmeleri örneği. Niğde Üniversitesi iiBF Dergisi, 6(1), 186-202.

Turan, 0. (1993). Türk cihan hâkimiyeti mefkûresi tarihi. İstanbul: Ötüken Neşriyat.

Yeşil, R. (2011). Mesleki eğitim perspektifinde ahilik sistemi: Tespitler-tahliller. 1. Uluslararası Ahilik Sempozyumu (1517 Ekim 2008) Bildiriler Kitabı, 2, 1117-1135.

Yeşil, R., \& Aslanderen, M. (2017). Ahilik değerleri ölçeğinin geçerlik ve güvenirlik çalışması. International Periodical for the Languages, Literature and History of Turkish or Turkic, 12(4), 565-584.

Zorlu, K., Merdan, E., \& Ege, Ö. (2012). Ahilik kültürünün günümüz işletmelerinde bilinirliği üzerine bir araştırma: Gümüşhane örneği. Journal of World of Turks, 4(3), 75-94. 